\title{
Technological Women and Artificial Erotics in the Late Nineteenth Century
}

\author{
Alex Goody
}

Debates about the relationship between women and technology are a prominent feature of late twentieth-century feminism. Donna Haraway's striking declamation in her "Cyborg Manifesto" "I'd rather be a cyborg than a goddess" articulates a central dichotomy that her socialist techno-feminism, 1 and subsequent conception of "naturecultures," 2 seeks to supersede. Discarding the restrictive idealisation of the "goddess," Haraway's "cyborg" stands as a creature "simultaneously animal and machine" who serves to reject the myths and dualisms which have sustained Western humanism.3 As my article argues, however, the challenge that Haraway's cyborg figuration poses can be unearthed in an earlier period. The late nineteenth century saw the development of the technologies that underpinned the twentieth century technosphere which inspired Haraway's “Cyborg Manifesto," 4 but it also witnessed the increasing technologisation of women's sexuality, evident both in the production of scientific knowledge about sex and sexuality and the invention of technical forms of mediation or treatment. Women benefitted from technological advances, finding new forms of employment as typists and new mobilities on their bicycles, but these potential freedoms were proscribed by a cultural imaginary that sought to recuperate the technologically-redefined woman back into a masculinist sexual economy and androcentric model of sex. Haraway's manifesto highlights that "sex, sexuality, and reproduction are central actors in high-tech myth systems structuring our imaginations of personal and social possibility" in the late twentieth century, 5 but as my article reveals, this characterisation can just as usefully be applied to the technological "myth systems" of a century earlier and its impingements on women's bodies and sexualities. 
The following pages discuss the disquieting women of the fin de siècle and focus on a pervasive correlation of femininity, artificiality, sexuality and technology, examining fictional and medical discourses which variously reinforce an androcentric sexual norm, the hegemonic pattern that had circumscribed women's erotic and reproductive lives from ancient times.6 As the tension between women's liberatory politics and the sexual mores of Decadence was often played out on the topography of the New Woman my argument focuses on those British and French writers who engage decadence, sexuality and the female body through tropes of artificiality and technological innovation.7 In examining the representation of women in late-nineteenth-century texts I consider how literary narratives negotiate, reinforce or redefine the cultural dynamics generated by new technologies of transport, inscription, and medicine. The "close technocultural readings" highlight the specific tropes that recur across texts concerned with women's bodies and their sexual relationship to men and to modern technology, modern tropes which function within an ancient myth system that asserts the dominance of man in contrast to the derivative position of woman. But what I also demonstrate, in the final consideration of two women writers who imagine artificial women and mechanised erotics that end up superseding a patriarchal sexual economy, is the potential for women's fin de siècle technological affinities to set a line of flight out of the masculinist, androcentric norm.

The unsettling potential of women's connection to technology at the end of the nineteenth century intersected in particular ways with anxieties about the New Woman and it generated responses that sought to regulate or deny that potential. To illustrate this process of regulation I begin by exploring the particular conjunction of women and artifice in Charles Baudelaire (1821-67) and the work of British writers influenced by Décadisme or published in The Yellow Book including Arthur Symons (1865-1945), Oscar Wilde (1854 
1900), and Max Beerbohm (1872-1956), and by examining the ways in which a proliferation of versions of the Pygmalion myth and representations of maquillage and the female performer in late-nineteenth-century writing stressed the artificiality of women. This fin de siècle feminine artifice can, as I go on to argue, be connected to the techno-affinities of the New Woman who is recaptured, in narratives that consider cycling and typewriting, by the normative heterosexual sexual economy that defines marriage and wifehood. The drive to capture the technological New Woman is paralleled by medical discourses and innovations, including surgical gynaecology, Jean-Martin Charcot's (1823-93) treatment of hysterics, and the clinical use of vibrators on female patients, medicine which either sought to place what was perceived as women's excessive (sexual) expression under the remit of technical control or to manufacture its normalisation through technology.

The myth of Pygmalion, the medical mechanisation of women's sexed bodies, and the anxieties about women's techno-affinities coalesce in a startling way in an early Science Fiction text by Jean-Marie-Mathias-Phillippe-Auguste, comte de Villiers de l'Ilse Adam (1838-89); his L'Eve Future (1886) postulates the creation of a totally artificial woman invented to serve as the ideal companion for a lovelorn English lord. My examination of L'Eve Future demonstrates how a masculine imaginary saw contemporary technology as a way to automate the myth of the artificial woman and in doing so produce a mechanism of control which refuses her any agency in and through whichever kind of technological affinity she might have. It is against the wielding of technology in the production of womanmachines who can be controlled, a technological myth-system which, as Haraway's analysis shows, continues to have very real implications for our world, that I examine the alternatives offered in Vernon Lee's (1856-1935) short story “The Doll” (1896) and in the women written by Rachilde (1860-1953). 
Artifice and Women at the Fin de Siécle

The artificial woman resonates in particular ways with the aesthetics of Decadence which emphasised the autonomy of art and celebrated artifice whilst offering visions of life and of sexuality that were deemed unnatural by the dominant mores of the Victorian era. Artificiality and aesthetic refinement function, not simply as central tropes of Decadence, but are instead seen an accurate reflection of fin de siècle modern life. Arthur Symons in "The Decadent Movement in Literature" points to artifice as the central truth of Decadence, and thus "its [Decadent literature's] very artificiality is a way of being true to nature." ${ }^{8}$ What can be discerned in specific decadent writers, though, is a distinct gendering of the "true [. . . nature" of artificiality; women come to represent both the fundamental artifice and its contemporaneity. Thus for Baudelaire there is a clear link between artifice, women's fashions for dress and maquillage, and modernity in his 1863 essay "Le Peintre de la Vie Moderne" ("The Painter of Modern Life"). Having already suggested "an indivisible unity" between Woman and her external presentation, the eleventh section of Baudelaire's essay is written "In Praise of Cosmetics" and continues his overall attempt to define and describe a fleeting modernity and to battle against the undirected impulses of nature: "Everything beautiful and noble" he writes "is the result of reason and calculation." Baudelaire argues that fashion should not be considered in the abstract, or simply as an object, but as the animated exterior of women's beauty, inextricable from women themselves; "fashions should never be considered as dead things; you might just as well admire the tattered old rags hung up, as slack and lifeless as the skin of St Bartholomew, in an old-clothes dealer's cupboard. Rather they should be thought of as vitalized and animated by the beautiful women who wore them." For Baudelaire women's beauty emerges in a vitalizing collaboration with artifice and 
the "trickery" of this effect is, despite the seeming oxymoron, a "duty" of womanhood, thus, "Woman is quite within her rights, indeed she is even accomplishing a kind of duty" when she uses cosmetics and "it matters but little that the artifice and trickery are known to all."” The conjunction between women and the "trickery" of artifice that Baudelaire draws is certainly not his own invention - indeed it echoes through the ages in Western literature. But what is new at the end of the century is that interest in how it is women's potential artificiality that is posited as simultaneously a key to their beauty and their potential modernity.

Although Baudelaire's emphasis is on fashion and cosmetics as the pre-eminent markers of women's modernity and their artificiality, the celebration of artifice and its association with women isoften exemplified in the body of the actress at the fin de siecle. The work of Oscar Wilde exemplifies the decadent valorisation of artificiality alongside a presentation of non-normative sexualities, nevertheless his The Picture of Dorian Gray (1891) inscribes some of the dominant patriarchal tropes through which the supposed artifice of the actress meant her reduction to the status of object. In the events that precipitate his succumbing to aestheticism and fall into moral turpitude Dorian becomes enamoured of the young actress Sybil Vane. In the throes of love Dorian explains how Sybil's artifice places her above the everyday artificiality of womanhood, declaring to Lord Henry that "the only thing worth loving is an actress" because of her ability, in playing roles, to rise above the "stereotyped smile" and "fashionable manner" of other women. 9 However, in falling in love with Dorian, Sybil herself loses her acting ability, declaring to Dorian, "You have taught me what reality really is."10 Although Sybil no longer feels akin to "the puppets of the play," Dorian only values her for her heightened artifice as an actress and thus rejects her; "without your art you are nothing."11 Moreover by turning his experience with Sybil into "a strange 
lurid fragment from some Jacobean tragedy" in his memory, ${ }_{12}$ Dorian completes her transformation into an artificial, male-authored artistic object, completely removed from the actuality of her life and terrible death.

That Sybil fails to live up to Dorian's ideal actress highlights how Wilde's text negotiates, alongside his obvious use of the Narcissus myth, the Ovidiean myth of Pygmalion; in Ovid's original the sculptor-king Pygmalion falls in love with the beautiful statue he has made and has his entreaties answered when Venus brings the statue to life. Wilde's text centres on Dorian and thus Dorian is the key figure in its Pygmalion revisioning: Basil Hallward, who is clearly deeply enamoured of Dorian, paints a portrait of Dorian which then lives the visible signs of Dorian's terrible decadent existence, while Dorian remains as the original portrait, young, beautiful and untouched. But the myth of Pygmalion informs also Dorian's response to the Sybil Vane: he is in love solely with Sybil as an artistic creation (when she is one of Shakespeare's women and not herself) and she is often described in terms of the "ivory" beauty of sculpture. Within the cultural dynamics that Wilde's text articulates, the actress is a woman acting the part of a woman, thus she is not just crafting an appearance through artificial means such as cosmetics, but coming into being as Woman only by taking up a role, identity and appearance created for her elsewhere. In the negotiation of the woman actress' public visibility and desirability the emphasis on artifice, rather than the active creativity of her acting, serves to return her to a passive role. This figure of woman as the passive object of (man's) creativity is reflected in the preponderance of the myth of Pygmalion in the Victorian era. 13

As Marie Lathers has explained, the Victorian period is characterized by its investment in a "Pygmalion complex," 14 in which an ancient myth gathers a new potency in attempts to negotiate the relationship between ideals of womanhood vital to the functioning 
of the patriarchy and the impact of women's liberatory politics. And as Gail Marshall argues in Actresses on the Victorian Stage: Feminine Performance and the Galatea Myth, the Victorian actress was often authorised and determined through sculptural analogies, specifically through the figure of Galatea, as Pygmalion's animated statue came to be called (she was nameless in Metamorphoses).15 The Pygmalion myth also influenced the emergent discourse of sexology and English sexologist Havelock Ellis (1859-1939) called a "rare form of erotomania" manifested in the "sexual love of statues" Pygmalionism.16 This unusual sexual pathology sought little or no actual contact, thus emphasizing how unimportant was the bodily reality of femininity for Pygmalionists. Further, as Ellis describes, Pygmalionism "is sometimes restricted to cases in which a man requires of a prostitute that she shall assume the part of a statue which gradually comes to life, and finds sexual gratification in this performance alone." ${ }_{17}$ Ellis's diagnosis points to a masculine interest in artificial erotics; the artificial construction of women and their sexuality and the erotic charge of the animated object. This framing of desirable Woman which returns her lived presence to the passive fixity of the sculptural object has an ancient origin in the workings of the patriarchy, but in the historical moment of the fin de siècle the technological affinities of Pygmalion's Galatea hint at the possibility that the sculpted and controlled object might be a technological one, an automaton or machine-being. Thus, as the discussion below goes on to show, the late Victorian resonances of a masculine creator fashioning an artificial woman who meets his ideals of femininity are shaped in concert with contemporary discourses, and anxieties, about women's relationship to emergent technologies and ideas of a technological self.

Victorian Technoculture and the New Woman 
The nineteenth century saw various developments in political theory and philosophy that engaged with ideas of a technological self or postulated versions of a mechanised individual. In the first volume of Capital (1867) for example Karl Marx (1818-1883) describes both humans and mechanical tools as detachable body parts with modern machines, a monstrous transformation of the worker's tool, threatening to subsume or supplant the industrial worker. Charles Babbage's (1791-1871) Economy of Machinery and Manufactures (1832) postulates humankind as empowered by the machine-as-prosthesis, while Thomas Carlyle's (1795-1881) conception of "Man [as] a Tool-using animal" places technology at the heart of the establishment of identity within the social polity.18 In literature Edgar Allan Poe (18091849) imagines a version of the self as not just extended by, but constituted in, technology, in “The Man That Was Used Up” (1939), while Herman Melville's (1819-1881) “The Tartarus of Maids" (1855) presents factory girls as "cogs to the wheels" of machinery.19 Harriet Martineau (1802-96), in articles examining factories in Northern England written for Household $W$ ords in 1852, poses a different idea of women factory workers, one which points to their technological prowess and genders a specific idea of physical enhancement through machine affinities. As Tamara Ketabgian describes "Martineau establishes a definitive compatibility between machinery and femininity, between the demands of the factory and the feminine tolerance for bodily manipulation," viewing "female-mechanical hybrids as promising and productive" whilst holding on to "notions of bodily integrity." 20 By the closing decades of the nineteenth century the very 'New' women who appeared both in fiction and in society gave a contemporary inflection to the technological self, recasting the older tradition of infatuation with an artificial creation, and forging links between women and technology that, in contradistinction to Martineau's female-mechanical hybrids, undermined the moral imperatives of bodily integrity. These modern, New Women who 
seemed to threaten the very foundation of the heterosexual sexual economy by refusing marriage and domesticity and opting instead for a visible presence in the intellectual and social economy, were characterised by a disruptive affinity with technologies of transport and communication.

The New Woman was a social reality and a cultural creation (in the pages of Punch, in newspapers in France and Britain, on the stage and in novels) 21 in which she was made to embody the advances of the age and associated threats to the androcentric status quo. In her attack on the emergent New Woman, or "The Girl of the Period" to use her terms, Eliza Lynn Linton (1822-98) identifies their assault on Christian, English virtues and the institution of marriage as lying in their very unnaturalness. Linton's Girl of the Period “dyes her hair and paints her face" in a "bad copy of a worse original" and is in fundamental opposition to the "essentially womanly" “old English ideal.”22 Max Beerbohm’s 1894 comic piece "A Defence of Cosmetics," published in the first edition of The Yellow Book, connects the pervasive Decadent valorisation of artifice and the artificial to contemporary anxieties about the New Woman through a focus on cosmetics. In this spoof Beerbohm commends the "painted mask that Artifice bids them [women] wear," the time and effort required to apply it, and the related "repose" that women need to adopt.23 In pointing to how technological advances in make-up benefit the modern women-"what gifts innumerable has Artifice been loaded by Science"-24Beerbohm suggests a reactionary link between technological advance and women. Even more, because "Artifice is the strength of the world," 25 Beerbohm suggests that cosmetics may actually save late-nineteenth-century society from the "horrific pioneers of womanhood" who have promoted a "seizure of the bicycle and of the typewriter" and threaten to occupy the House of Commons.26 Beerbohm opposes two versions of contemporary artificial women: the woman of cosmetic artifice with the 
new, artificially-enhanced woman, mechanically reconfigured by the bicycle and typewriter and physically and politically empowered by such machine affinities.

Beerbohm’s “A Defence of Cosmetics” highlights how the New Woman was not only associated with unnatural habits of dress and behaviour, but also specifically with new technology. In this the bicycle played an important role quickly becoming "associated with new female freedoms." ${ }_{27}$ But in both popular romantic fiction and New Woman novels, cycling represented a problematic liberation for women where "physical independence and freedom [may be] at the cost either of regression to a kind of pre-sexual state or of difficult male-female relations." 28 As had been the case with train-travel and horse-riding, some worried about the possibility of a concealed onanistic pleasure accompanying the apparent independence of the lady cyclist (or lady train-traveller) which provoked ambivalence about women's use of this travelling technology.29 In texts such as Mrs Edward Kennard's (18501936) The Golf Lunatic and his Cycling Wife (1902), cycling is explicitly a vehicle for liberation, as the "Cycling Wife" Cynthia Jenningham declares:

What a field of new experience the cycle opened up to modern womanhood! It freed her from a multitude of conventional shackles. [...] [D]ependent on no man, no horse, no carriage, but solely on the clever bit of mechanism constructed by the ingenuity of human brains and hands.30

This liberation and release from androcentric norms ("conventional shackles" and "man") through "the clever bit of mechanism" acts as a compensation for the sexual frustrations of an unfulfilling marriage, but Cynthia is only temporarily emancipated. Cycling functions in order to finally reconcile her, after a period of independence and physical activity, to the 
passivity and stasis of the domestic sphere. In this narrative return of the wife to a heterosexual norm, Kennard's novel clearly negotiates an anxiety about women's (erotic) association with technology.

The visibility of the New Woman cyclist in her divided skirt can be connected to another increasingly visible technological New Woman, the typist. Morag Shiach details how, from the first commercially produced typewriter in 1867 onwards, the typewriter has been seen to have special significance for women.31 Indeed as Christopher Keep notes, women's success in the clerical workplaces of the 1890s "was popularly explained by arguing for a 'natural fit' between the values of femininity and the skills required by the new machines of mechanical transcription." ${ }_{22}$ While Shiach is right to resist a simple causal link between the invention of the typewriter and the "entry of women to the office," the very new mechanical reconfigurations of bodily actions enabled by inventions such as the typewriter and bicycle played a key role in ongoing discourses about women's independence, their sexuality, and their relationship to artificiality. 33

British fiction of the period returns regularly to the type-writer girl, expressing “uncertainty about the typewriter as a technology of emancipation.” ${ }_{34}$ Conan Doyle’s (18591930) story "A Case Of Identity" (1891) centres on the sadly beguiled typist Miss Sutherland while in Gissing's The Odd Women (1893) the Typing School may seem to be a force for the economic and social liberation of women, but the lonely end of the School's director, Rhoda Nunn, suggests typewriting is "a deadening negation of the sexual." ${ }_{35}$ In a similar vein Grant Allen (1848-99) [writing as Olive Pratt Rayner]'s 1897 The Type-writer Girl tells the story of Girton Graduate Juliet Appleton seeking financial autonomy, who returns to the position of a typist after frustration in both her experiment with anarchist commune membership and her relationship with her already affianced employer. Typing in these texts, perhaps like 
cycling, seems to offer liberation and independence, but these technologies are fundamentally at odds with normative, androcentric (heterosexual, reproductive) sexuality, something that places the typist in a similar position to the governess whose "sexuality was the subject of intense scrutiny, idealisation and attempted regulation throughout the first part of the Victorian period." ${ }_{36}$ However what distinguishes the typist, through her affinity to new communication technology, is her automatic potential, meaning she could fall completely outside the integrity of bourgeois femininity. "Type-writer" designated simultaneously the woman who operated the machine and the machine itself, and the erotic potentials of the mechanically attuned type-writer girl provoked pornographic imaginings alongside speculations about the type-writer girl as self-sufficient woman-machine, a type of automaton or uncanny technological Medium.37

Bram Stoker's (1847-1912) Dracula (1897) most fully exploits the deep anxieties about the new communications technologies of the late-nineteenth century, particularly the typewriter. Critics have noted the prominence of the typewriter in the novel, arguing that technology underpins the "dizzy contradictions" of Dracula and proposing that "as radically different as the sexy act of vamping and such prosaic typewriting appear, there are underlying ties between them." 38 Mina's industrious typing for her husband-her transcriptions of the text's stories and sexual secrets-endangers her and the safe femininity she represents, a danger actualized in her psychic-sexual bond with Dracula. In Mina, Stoker inscribes the peculiar fascination of the female automaton as she passes from being a dutiful woman working her typewriter to a passive mechanism controlled by the voracious Count. As an uncanny technological woman, a mechanical product of male industry and intelligence who nevertheless hints at a dangerous sexual unorthodoxy, the figure of Mina manifests some of the anxieties about non-normative female sexuality, a sexuality that, within the 
terms of Stoker's novel, needs to be made monstrous and annulled. But in Dracula it is the other woman, Lucy Westenra, who is vividly destroyed in a symbolic reassertion of androcentric sex:

The body shook and quivered and twisted in wild contortions. The sharp white champed together till the lips were cut, and the mouth was smeared with a crimson foam. But Arthur never faltered. He looked like a figure of Thor as his untrembling arm rose and fell, driving deeper and deeper the mercy-bearing stake, whilst blood from the pierced heart welled and spurted around it.39

Vampire Lucy is expressly marked as sexually uncontrolled and an horrific perversion of the roles of wife and mother in Dracula, stalking the streets of London and preying on children. Her violent, sexualised destruction by her fiancé is the inverse of Mina’s happy ending: a wife and mother at "home" and safe from the "mass of typewriting" that records their encounters with Dracula.40

\section{Vivisection, Hysteria and the Technologisation of Women's Bodies}

The graphic, sadistic, and sexualised destruction of Lucy in Dracula who has a stake driven into her body by the men who seek to cure her vampiric manifestation, points towards a further prominent feature of late-nineteenth-century culture and the mechanisation of bodies: the practice of vivisection. The scientific dissection of the body in vivisective practice functions through a primary reduction of the body to a set of mechanical functions that can be dissected and understood. This mechanical model of the body has its origins in the emergence of materialist science in the 1700s but the conception of the body as a 
technological object held a particular import in the culture of the late nineteenth century at a time when women's bodies were coming under the increasing scrutiny of the medical profession. New Women writers such as Mona Caird (1854-1932) and Francis Cobb (18221904) published antivivisectionist tracts, 41 and there was a convergence of the feminist and anti-vivisectionist movements in France in the 1880s and 1890s.42 Thus, there was more than just an implicit parallel between the amoral horror of live animal experimentation and the gynaecological medicine that had emerged as a distinct practice in the latter part of the nineteenth century. Gynaecology, which used innovations such as the speculum and anaesthesia, could enable prurient and invasive medical practices on powerless woman and provoked much controversy.43

Particularly within the popular women's movement in Britain to repeal the 1860s Contagious Diseases Acts, which imposed compulsory venereal disease checks and potential internment in Lock Hospitals on prostitutes, it is possible to see the links that can be, and were, made between the treatment of animal subjects by medical science and the treatment of women strapped to tables in gynaecological examinations and operations. The dedicated antivivisectionist doctor Elizabeth Blackwell (1821-1910) observed the "horrible exposure" of women in public hospitals, 44 and as Sarah Stage describes, she "abhorred vivisection [and] fought sexual surgery on the grounds that doctors who experimented on live animals were simply extending their experimentation to female patients." 45 Blackwell, and other women doctors such as Anna Kingsford (1846-88), connected vivisection to the invasive sexual surgery that some gynaecologists practised on women: writing in the Lancet in 1876, for example, Dr. Robert Battey (1828-95) asserted that the removal of healthy ovaries could treat a range of female symptoms related to "mania." ${ }_{6}$ This mechanistic and abusive 
approach to women's sexual and reproductive body exemplifies the dangers of reducing women to a mechanical object that can be re-engineered through technical means.

Numerous writers in the late nineteenth century explored the relationship between vivisection and a dangerous sadistic eroticism. Dr. Benjulia in Heart and Science (1883) by Wilkie Collins (1824-89), for example, is a vivisector who also likes to study (and tickle) little girls. The brutal and sexually charged power of the vivisector is exposed by the New Woman writer Sarah Grand (1854-1943) in the figure of Dr Daniel Maclure in The Beth Book (1897): Beth is married off unwillingly to Dan, a superintendent of an institution for the confinement of women with venereal disease (a Lock Hospital); once she learns that her oppressive and philandering husband is also a vivisector, however, she leaves him.

Debates about vivisection, and the implicit perverse masculine eroticism that often accompanied it, overlap with both the medicalisation of women's bodies in obstetrics and the sadomasochistic dimensions of Victorian pornography. There was thus an erotic potential in the figure of the woman as mechanical object, exposed to the sadistic male gaze and made available for experimentation. As Coral Lansbury writes "the vivisected animal stood for vivisected woman: the woman strapped to the gynaecologist's table, the woman strapped and bound in the pornographic fiction of the period." ${ }_{47}$ In attacking vivisection, therefore, many women such as Caird and Cobbe were also defending their own, and similarly othered, bodies from an intrusive, prurient and objectifying technologisation and medical gaze: "will they advocate doing the same to a score of Bosjemen, to the idiots in our asylums, to criminals, to infants, to women?" Cobbe speculates in The Modern Rack: Papers on Vivisection (1889).48

In her novel La Marquise de Sade (1887), the French woman writer Rachilde, juxtaposes two sadistic doctors, one whom specialises in vivisection, the other in hysteria 
and this points to the connections between the abuses of vivisection and a surprising technological discourse of women's sexuality in the late nineteenth century, one in which a conjunction of the machine dreams of the Victorian age with ideas (and fears) about women's role and sexuality is manifest in medical attempts to mechanise and organize the eroticism of female hysteria. Charcot's treatments at his clinic at La Salpêtrière in Paris, and the mechanisation of an ancient technique for the relief of female maladies—manual genital massage to orgasm by a physician or midwife (a technique endorsed by the Hippocratic corpus and subsequent medical literature)—both illustrate how the hysterical body was caught up and re-engineered or automated through contemporary technology.

At the Salpêtrière Charcot's hysterical patients demonstrated an impressive range of involuntary symptoms including contortions, mutism, spontaneous blindness or deafness, erotic delusion, hallucinations, choking, catalepsy and convulsions. In his attempt to treat the source of these symptoms Charcot used a range of technologies, including hypnosis, hypnotic imprinting, hysterogenic zones, electric shocks, graphs and charts, plaster casts, and especially photography. The Tuesday leçons at the Salpêtrière have become well known for their spectacular staging of hysterical attacks for an audience that often included artists and writers as well as medical students. Notable clinical subjects, like Blanche Wittman (1859_ 1913) and Augustine Gleizes (b.1861), achieved a kind of fame that still resonates through studies of La Salpêtrière.49 More pertinent for this argument, the famous actress Sarah Bernhardt (1844-1923) drew inspiration from her visits to Charcot's demonstrations. At the Tuesday leçons the hysterical subjects were controlled through hypnosis and animated by a variety of means including what Felicia McCarren describes as "sustained electrical treatments." ${ }_{50}$ The photographic images collected in Iconographique photographique de la Salpêtrièresı(1876-80) are not only records, but also technical productions of hysterical 
bodies, 52 and in these photographs, Charcot's patients become a kind of automata. Charcot claimed the position of visual technician declaring "all I am is a photographer. I describe what I see." 53 There has been much recent critical attention to the visual emphasis of Charcot's practice but less attention has been paid to the role of technology, particularly how Charcot's dismissive description of himself as merely a "photographer" effaces the creative role of the technologically empowered clinical eye, putatively erased through photographic technology. 54

As his lectures illustrate, key to Charcot's nosography of hysteria was the discovery of ways to control and manufacture its symptoms. Charcot's technique of ovarian compression could, he claimed, "determine the production of the [hysterical] aura, or sometimes even a perfect hysterical seizure." 55 In a co-authored article Charcot, with Paul Richer (1849-1933), describes the electric stimulation of the facial muscles of a hypnotised hysterical patient in Pygmalionesque terms: "The subject is thus transformed into a sort of expressive statue." 56 They also point out how their use of electrical stimulus provoked "attitudes . . eminently favourable to photographic reproduction," alongside plates of these exemplary photographs of the physiognomy of hysteria.57 In different ways Charcot used technology to make automata out of his patients: as Asti Hustvedt points out, Charcot saw the hypnotised hysteric as the epitome of the technological subject, claiming that "it [the hysteric] is truly, in all its simplicity, the man-machine dreamed of by La Mettrie (1709-51), that we have before us." 58 In his efforts, Charcot sought to manifest and perfect an artificial form of the disease in hypnotised subjects, so that he could manipulate and control its symptoms. Put differently, the woman hysteric is available for scrutiny and potential cure only by becoming artificial, controlled and mediated through technological processes. Charcot's is an idea of the hysteric as an animated sculpture or an automaton to be reprogrammed, an artificial 
woman whose excesses can be controlled with technique and technology.

The technological interventions at Salpêtrière were not only organized by automatism. The medicalisation of hysteria converged with the vogue for hydropathy and electrotherapeutics at the time to produce new mechanisms to replace the traditional medical treatment for this supposed disease of women. Indeed, hysteria is fascinating because it was simultaneously said to have a sexual origin and to require sexual excitement or containment (marriage) as its cure. Rachel Maines has discovered that the period between the 1880s and 1920s saw the widespread medical administration of vibrators to hysterical female patients in Britain, Europe and America.59 The electromechanical vibrator, used at Salpêtrière in 1878,60 patented in the 1880s, and manufactured by the British medical instrument maker Weiss, revolutionised a doctor's ability to treat his paying hysterical female patients:

Massage to orgasm of female patients was a staple of medical practice among some (but certainly not all) Western physicians from the time of Hippocrates until the 1920s, and mechanizing this task significantly increased the number of patients a doctor could treat in a working day.61

In sum, hysteria is aligned with technology in two ways in the late nineteenth century: Woman is seen as mechanical and artificial, this is part of her desirability but also something which could be replaced by better technology; her hysteria and misplaced sexuality are mechanical failings that can be treated with technology; technology thus enhances woman, she has an affinity with it, but this affinity and its attendant eroticism present a very fundamental threat that men seek to dominate. When read alongside anxieties about the New Woman's potential technological liberation what becomes clear is that the gender 
politics of Haraway's description of the late twentieth century also pertain here; the fin de siècle technological myth systems which structure imaginations of personal and social possibility, and validate invasive medical practices, reinscribe patriarchal and androcentric norms for modern women's sexuality and reproductive capacity.

Female "Andreids" and Dolls at the Fin de Siécle

The work of Charcot in automatizing hysterics, the sexual-electrical control of women, and the vivisector's voyeuristic gaze all generate the cultural dynamics that are negotiated in a late-nineteenth-century French text profoundly concerned with the modern woman: Villiers's L'Eve future (The Future Eve). As a 'fully-fledged SF novel',62 The Future Eve engages with a gamut of emergent and speculative technology (including phonography, telephony and cinematography) but it is also a novel deeply disturbed by the mechanistic contemporary world and misogynistically dismissive of women. In both cases Villiers negotiates what he sees as the threat of mediocrity and materiality posed by a world of commonplace reproduction. The alternative that The Future Eve presents is to see technologies of recording and duplication, and concepts of the technological self, as the means to replace real women with an ideal automatic alternative.

In Villiers's text a fictionalized Thomas Edison, the "SORCERER OF MENLO PARK" ${ }_{63}$ is inspired to create an "andreid," called "Hadaly," after discovering the artificial nature of the beauty of a woman who seduced and destroyed his close friend.64 Edison learned that the suicide of his boyhood friend Edward Anderson was the result of an adulterous involvement with a professional dancer named Evelyn Habal and his investigations reveal the reality of the woman who has produced the "frightful degradation" in his friend.65 Edison presents this woman to another friend Lord Ewald, who is visiting his 
laboratory, in a projection produced by one of the marvellous mechanisms that furnish the Menlo Park rooms:

A long strip of transparent plastic encrusted with bits of tinted glass moved laterally along two steel tracks before the luminous cone of the astral lamp. Drawn by a clockwork mechanism at one of its ends, this strip began to slide swiftly between the lens and the disk of a powerful reflector. Suddenly on the wide white screen within its frame of ebony topped by a gold rose flashed the life-size figure of a very pretty and quite youthful redhead.66

Evelyn appears as a cinematographic replication, produced by fictional mechanisms (this text pre-dates Edison's premiere of his Kinetoscope in 1894 and the Lumière brothers' 1895 Cinématographe), but she is an artificial creation in a much more profound sense than the manufactured hysterics of Charcot's Salpêtrière photographs. The subsequent chapter of The Future Eve, "Exhumation," depicts the "true remains" of Evelyn Habal which Edison keeps in a drawer: wigs, girdles, falsies, make-up, perfumes, and abortificants. Indeed, the list of artificial enhancements, the "real machinery" that produces Evelyn's attractions perform a complete dissection of her face and body, unpacking her false hair, teeth, complexion and bust, her perfumes, corsets, stuffed stockings and shoes with lifts.67 Stripped of "all her alluring devices,"'68 the second projection of Evelyn differs markedly from the first:

On the screen appeared a little bloodless creature, vaguely female of gender, with dwarfish limbs, hollow cheeks, toothless jaws with practically no lips, an 
almost bald skull, with dim and squinting eyes, flabby lids, and wrinkled features, all dark and skinny.69

The audience for Edison's demonstration of Evelyn's “devices' and “machinery”, Lord Ewald, has also been fatefully deceived by the femininity of the performing woman he loves. The actress Miss Alicia Clary is, rather than a being composed of cosmetic prostheses, a disappointing Galatea. Alicia has a body that "is molded in lines to delight and surprise the greatest sculptors ... she has indeed the splendour of a Venus Victorious, but humanized".70 Unfortunately for Ewald, and unlike Pygmalion's animated statue, Alicia has a clearly defined character and one that reveals for Ewald "an absolute disparity" between her form and her “self": 71 Her "mind is nothing but the marketplace" as Ewald puts it.72 Ewald's attempt to inspire Alicia's aesthetic sense by taking her to see the Venus de Milo fails miserably: Alicia experiences a moment of recognition - "Look it's ME"! - that is immediately tempered by her bourgeois practicality; “Yes, but I have arms.” ${ }_{33}$ Wilde's Dorian Gray rejects his failed actress-Galatea, who then destroys herself, but Edison's proposal for Ewald is different; a complete and exact replacement for Alicia, an artificial being who will match Alicia's form in every detail, made from the andreid, Hadaly, he has invented.

The experiment that Edison is currently conducting, as he reveals to Ewald, is to create a wholly artificial woman, who would no longer be governed by the whims of biology or her own volition but would instead rely on the electrical and technological advances of man. In so doing, Edison seeks to replace the ugly reality of femininity and female sexuality with technology, and here the "invocation of the Pygmalion myth is explicit." 74 Edison's experiment would improve Ewald's situation in two ways: it would guarantee that the women match outside and in (and both would be artificial) and it would release men, here 
represented by Ewald, from the suffering they endure because of the base femininity of their partners, whose perfect exterior masks a mechanistically unthinking self.

In order to convince Ewald to trade up to a better model of Alicia, Edison introduces him to Hadaly and to the workings of Hadaly's andreid form. Drawing on the voyeuristic and sometimes sadistic perspectives validated in contemporary medical practice, this is done in intricate, extensive and vivisective detail. Hadaly is placed on a "porphyry table" "lying on it like a corpse on the dissecting table" while Edison activates one of her rings by which her "feminine outer integument slowly drew open." 75 We are then taken through all the aspects of Hadaly's electromagnetic mechanism, the electrical wires and currents that animate her, the golden disks that govern her speech, the disks and joints that facilitate her movement and balance and the battery that powers her:

Meanwhile, the electrician had touched a small enclosed transparent vessel full of distilled water located within the chest cavity of the [Andreid]. The concentrated carbon grid inside it slipped, at the almost imperceptible turn of a screw, into the water, and the current began to hum.

Suddenly the interior of the armature lit up like a human organism, flashing here and misty there, spangled with golden gleams and glittering lights.76

The text lingers with the details of Hadaly's interior, presenting the technological beauty and marvellous precision of her construction, implicitly contrasted with the grotesque "machinery" through which Eveyln Habal had achieved her appearance. Hadaly is the technological incarnation of the Pygmalion myth: an automaton created as a reflection of, and under the command of, masculine desire. As Edison explains, "since all these women 
are more or less artificial, since it is Woman herself who suggests the notion of being replaced by the Artificial, let's spare her the trouble." 77 Hadaly, a simulacrum with a finite number of movements, gestures and conversations- her conversations will all result from sixty hours of recordings of Alicia's voice played on two golden phonographs in her chestreleases men from their enslavement to real femininity, replacing women with the manifestation of masculine desire.

At the same time, however, Hadaly is also a mysterious and potentially emasculating figure. She is a machine that threatens to take on a life of its own; firstly as Ewald mistakes the completed andreid for the living Alicia and subsequently when it seems that Hadaly has an identity outside of the finite movements and responses that Edison has given her to reproduce.78 Indeed Hadaly's dangerous potential lurks behind Villiers's text which obsessively dissects and controls her. She is stored and transported in a coffin-like box and is ultimately destroyed when the cargo compartment of the steamer in which she is being transported by Ewald catches fire. As an artificial woman who provokes Ewald's ardent affection but who seems to exceed the command of her male operator-owner, Hadaly's destruction is a textual inevitability in this fin de siècle SF novel that is inspired by a desire to assert control over women and machines.

An 1896 story by Vernon Lee "The Doll", offers a different perspective on the artificial creation of femininity, one which poses the possibility of a New Woman emancipating the idealised woman partner from her objectification and passivity under the control of men.79 Lee herself presents an interesting link between the New Woman and Decadence: an independent and non-heterosexual woman, influenced by German, French and Italian literature, aligned in scholarship both with New Woman writers such as Olive Schreiner (1855-1920) and George Egerton (1859-1945), and with Walter Pater (1840- 
1905),80 sensitive to and critical of Oscar Wilde, Lee’s position is described by Dennis Denisoff as a "combination of Decadent aesthetics and socialist sympathies". 81 In "The Doll" Lee articulates a liberation of femininity that utilises but also exceeds discourses of the New Woman and the Decadent affiliation to perversion and artificiality. Her story offers an important counter-narrative to the proscriptive accounts (in fiction, medicine and so on) which seek to contain the bodies and sexualities of modern women.

In "The Doll” the unnamed woman narrator encounters a strange artefact whilst visiting Italy alone on a trip to buy antiquities. Whilst being taking round an old palace the narrator sees what she thinks is a woman:

There was a woman in 1820 costume seated opposite, quite motionless. It was a huge doll. She had a sort of Canova classic face, like the pictures of Mme. Pasta and Lady Blessington. She sat with her hands folded on her lap and stared fixedly.

"It is the first wife of the Count's grandfather," said the old woman. "We took her out of her closet this morning to give her a little dusting."

The Doll was dressed to the utmost detail. She had on open-work silk stockings, with sandal shoes, and long silk embroidered mittens. The hair was merely painted, in flat bands narrowing the forehead to a triangle. There was a big hole in the back of her head, showing it was cardboard.

"Ah," said Orestes, musingly, " the image of the beautiful countess! I had forgotten all about it. I haven't seen it since I was a lad," and he wiped some cobweb off the folded hands with his red handkerchief, infinitely gently. "She used still to be kept in her own boudoir." 82 
The pronomial slippages between "she" and "it" in the passage continue throughout the story, verbally enacting the ambivalence that the Doll provokes: "I scarcely know whether I ought to call it a thing," remarks the narrator.83 The Doll is both an ideal Woman, created by the Count to replace his young wife after her death, and a lifeless object kept in a cupboard. As the story unfolds it becomes clear, at least for the narrator of the story, that the Doll is not simply a replacement for a dead woman, but an artificial creation that reveals the always already artificiality of the Count's idea of his wife. In the story the narrator tells, the young wife is married straight out of a convent and is simply present for her husband as a silent object of desire, secluded from the world and existing only for him and his love. Her replacement by a life-size cardboard doll on her death does not disrupt the continuity of the Count's love for her as he visits her every day in her boudoir, even after he begins an affair with his laundress.

Because of their shared gender the narrator experiences a kind of natural affinity with the Doll, "as if I had just ... rushed into a sudden friendship with a woman whose secret I had surprised," 84 and she knows "everything about her" without being told her story, seeing the Doll and the wife as the same thing - "for I made no distinction between the portrait and the original." ${ }_{55}$ According to Mary Patricia Kane, "[a]s the representation of the widower's subjective ideal of his wife, the Doll effectively replaces the original that it was meant to copy ... an imitation of her that has become more 'real' than she ever was or ever had the chance to become." 86 At the end of her trip the narrator feels unable to "abandon" the Doll and she decides to offer to buy her from the Count and have her transported in a “closed carriage” to her guide, Orestes's house.87 In another climactic scene where an artificial woman is burnt, the narrator cremates the doll in Orestes's garden and, as Orestes 
comments "you have put an end to her sorrows". 88 The uncanniness of the Doll- the fact that she/it functions "as a meditation on the difficulty inherent in drawing the borderlines between the 'real' and the 'artificial"' ${ }_{99}$ and haunts the narrator until she decides to buy it and destroy it—echoes other tales of the artificial human, notably E. T. A. Hoffman's (17761822) earlier story Der Sandmann (The Sandman) (1814), not least because of the central place Der Sandman would play in Sigmund Freud's essay on "The Uncanny" (1919) two decades after Lee's story.90 However, the destruction of the artificial woman in Lee's “The Doll” is not the punishment that is meted out to Hoffman's clock-work doll Olimpia or to Hadaly. Lee's "The Doll" sits within a framing narrative that comes at the end of the Introduction in For Maurice: Five Unlikely Stories in which "The Doll” was published.91 Here Lee writes that "this story is not by me at all, nor do I know whether it is by anybody, or, so to speak, a natural product... For the story was told to me (I adding only a perhaps unnecessary ending)." 92 This introduction further disturbs the boundaries between the "natural product" and "story" that "The Doll” itself explores: Lee's “The Doll” is not her invention — she claims she herself saw the Doll and was told her/its story by a friend—nor is it quite the inevitable or "natural" manifestation of women in the patriarchy. Lee serves to both abnegate her role as author and claim responsibility for the ending of the tale, thus showing that the artificial woman is an ideal created elsewhere, but that the woman author can rewrite the "story" of artifice and change the destiny of this "product" of androcentric sexuality. Lee's is an ending added to propel the narrative (if not the "happily married" but momentarily single narrator of "The Doll") beyond the immortal confines of male-authored desire. What Kane describes as an "iconoclastic finale" ${ }_{93}$ is not therefore a destruction of the threat that the Doll poses. In contrast to Sybil's suicide, the burning of Hadaly, or indeed Mina Harker or Cynthia Jenningham's married state, Lee's story releases the Doll/woman 
from the constraints of a heterosexual matrix that casts her as the passive product of male desire. 94

Lee's liberation of "The Doll” from her status as "wife" thus serves as a rejection of masculine-centred desire and points towards the possibility of a different mode of being. The ending that Lee proposes resonates with the possibility that artificial or unnatural women, despite attempts to capture them in androcentric narratives that reduce them to the passive role of Galatea or the Venus de Milo, might escape this objectification-even Alicia Clary notes in The Future Eve (1886) "I have arms". Further than this, it is possible to locate late-nineteenth-century textual versions of an artificial, technological feminine erotic that takes women right outside the reductive dualisms of androcentric sex, that instead reduces men to, or replaces men with, a mechanical construct, a phallic prosthetic at the command of the pleasures of women.

Fin de Siécle Artificial Erotics and Women's Sexuality

The work of Rachilde known as "Mademoiselle Baudelaire" (her given name was Marguerite Eymery), exemplifies the central Decadent rejection of normative sex and sexuality. In her life Rachilde styled herself a "man of letters" in the circles of Decadismé and her female protagonists refuse the role of reproductive feminine and the feminine role altogether in many cases. Éliante in La Jongleuse (The Juggler), (1900) adopts a variety of feminine disguises and performances but always frustrates her suitor Léon's expectations of sexual union; Mary Barbe in La Marquise de Sade fantasizes about murdering a male transvestite "with pins glowing red from the fire", and Raoule in Monsieur Venus (1884) is the cross-dressing seducer of her feminised lover Jacques. But Rachilde is not simply writing female Decadence; 95 her work is a fertile site for uncovering an empowering vision of dangerous and challenging 
ideas about woman's autonomous sexuality. Crucially, Rachilde does not fetishize or objectify her heroines, "refus[ing] to focus the gaze of the reader onto the eroticised, fetishized body of the female object of desire," and instead highlighting the fabrication of desire itself and "displac[ing] their erotic charge onto those apparently incidental items which surround her heroines." 96 This narrative strategy combines with Rachilde's emphasis on autonomous sexuality to produce visions of women's desire, eroticism and pleasure as fundamentally prosthetic or technological in origin, a conception which resonates with the New Woman's cycling or typewriting autonomy. Not just displaced, therefore, to refuse "the voyeuristic reader," ${ }_{97}$ the eroticism of the prosthetic women of Rachilde's texts stand wholly beyond the proscriptions of heterosexual or reproductive sex.

Rachilde's Monsieur Venus epitomises the prosthetic women that Rachilde imagines with its heroine inverting the dynamics of heterosexuality in her marriage to the workingclass Jacques. The way that Jacques's body in Monsieur Venus is objectified and fetishized makes it clear that this text deals in the "aestheticization of masculinity",98 and that Jacques is associated with the "unnatural" and "artificial". 99 When Raoule has installed Jacques in the apartment she has rented for him she voyeuristically watches him, teases him and dominates him until he submits to her in a feminine role: "[he] became hers to do with as she would, a lifeless object who let himself be loved." 100 Jacques becomes the lover that Raoule wants, enabling her to avoid heterosexual intercourse and leading her to wonder "whether she, godlike, had not created a human being in her own image." 101 These Pygmalionesque implications are heightened when Jacques is described as an "Antinoüs" the youth deified (and embalmed) by Hadrian, by his own acknowledgement that his "body was a poem", and in the scene where he lies on the nuptial bed surrounded by cupids and a marble Eros;102 all transforming the living Jacques into an idealised object (embalmed god, poem, sculptural 
tableau). At the end of the story Jacques dies in a duel organised by Raoule, the ultimate act of her fabrication of his life and self. After his death, though, he is transformed into what Rita Felski identifies as a "male cyborg:" 103

on the bed shaped like a shell, an Eros of marble watches over a wax figure covered with transparent rubber. The red hair, the fair eyelashes, the gold hair of the chest are natural; the teeth that are in the mouth, and the nails on the hands and feet, have been torn from a corpse. The enamelled eyes have an adorable look. [.. .] At night, sometimes a woman dressed in mourning, and sometimes a young man in evening clothes, opens this door.

One or the other kneels at the foot of the bed, and, after contemplating at length the marvellous lines of the wax statue, embraces it, and kisses it on the mouth. A hidden spring, installed at the inside of the hips, connects with the mouth and brings it to life.

This wax figure, an anatomical masterpiece, was fabricated by a German.104

That the Jacques automaton is an "ideal substitute" 105 is implicit in his ambiguous activation, where a sexual embrace triggers an oral/genital response that provides Raoule with automatic satisfaction. Jacques, who before his death has figured as an aestheticized and passive object of desire, has been transformed into a kind of animated dildo, the ideal mechanical object who fulfils the desire of his owner-operator, facilitating her perpetually escape from the confines of androcentric sex.

Rachilde's The Juggler also provides a powerful example of female self-pleasuring that excludes the male lover/reader and suggests the supreme satisfaction of prosthetically 
enhanced female solitary pleasure in a key scene. Éliante, after warning Léon of her distaste for the humiliation of heterosexual union, turns to a human-sized white amphora. She first extols and eroticises the beauty of the amphora and then proceeds to embrace it and bring herself to orgasm as Léon watches this "display of solitary self-contained jouissance:" 106

Éliante, at present standing over the neck of the white amphora, became taut as a bow from head to foot. She was not offering herself to the man, she was giving herself to the alabaster vase, the one insentient person on the scene. Without a single indecent gesture, arms chastely crossed on this slender form, neither girl nor boy, she clenched her fingers a little, remaining silent, then, the man saw her closed eyes flutter, her lips half open, and it seemed that starlight fell from the whites of her eyes, from the enamel of her teeth; a slight shudder traversed her body — or rather a squall lifted the mysterious wave of her dress — and she gave a small groan of imperceptible joy, the very breath of orgasm.107

I would disagree with a critic like Rae Beth Gordon, who reads Éliante's orgasm as conclusive evidence of her hysteria, 108 but such a reading is telling. It recalls the connection between women's sexuality, hysteria, and technology that fictional and scientific discourses in the late-nineteenth century sought to manage and contain within a normative technology of sex. Rachilde's heroines cannot be returned to the safety of androcentric sexuality, captured by the hysteria machines of the Salpêtrière, made monstrous, or replaced. What Éliante achieves at this moment is the height of technical stimulation, replacing the male with an artificial phallic object - like Jacques-the-cyborg - that manufactures female orgasm 
with no reference to a (re)productive norm of female bodily roles. Rachilde's texts signal how women's erotic interaction with technological objects can take them beyond the dominant technologies of sex, rejecting the confines of the phallogocentric discourses of hysteria and medicine (with their fundamentally androcentric bias). Instead of reduction to a mechanical sexuality, such late-nineteenth-century machinic erotics signal the possibility of a blurring of conventional systems of binary classification and the emergence of a modern inorganic, autonomous "female" sexuality. 109

At the end of the nineteenth century a range of discourses and texts postulate the merging of myths of the animated statue with real technological and artificial women, and succumb to a profound fear about women's autonomy and sexual functioning. In novels and in the emergent treatments for hysteria, women are presented as the embodiment of artifice and dangerous technological New Women are shown to be threatening the androcentric foundations of culture. Such texts propose women's containment within artificial structures and structures of artifice, they attempt to control the disobedience of women's bodies and selves, to penetrate their psychic and somatic mechanisms, and manufacture an ideal technological femininity that is simply a projection of male desire. Both Lee and Rachilde challenge this male-authored version of artificial woman and in their different ways allow their women to take flight from it. Moreover, the very contiguity between women and the technological and artificial undermines the dualisms that male desire needs in order to operate: the medical application of vibrators for example, contains within itself the formula for women's own strategies of escape from a functional, androcentric sexuality.

As vibratory technology became more popular and went into mass-production near the end of the century, it became possible and affordable to purchase this equipment for the 
home. Models such as the "Vibratile", the "Bebout Vibrator" and the "Corbin Vacuomasseur" were advertised and available in department stores and by mail order.110 Sold as beauty aids and home massagers, they could also come with attachments for a variety of home uses. The sexual function of these gadgets, obvious but disavowed in their medical application for hysteria, could not be disavowed indefinitely and as they started to appear in stag movies in the 1920s, they slowly disappeared from medical view. The reappearance of vibrators as sex aids at the beginning of the period of postmodern technological experimentation and their increasing visibility in our culture does not mark a new era in female sexuality, nor though does it signal a desperate attempt by women to compensate for a phallic lack.111 What my article has revealed are the very prescient disruptions to an androcentric norm that late-nineteenth-century technological women posed, ones that are rediscovered and not reinvented in the empowered woman-machines celebrated in twentieth-century cyberfeminism.

\footnotetext{
1 Donna Haraway, "Manifesto for Cyborgs: Science, Technology and Socialist Feminism in the 1980s," Socialist Review 15, no.2 (1985): 65-107. Reprinted in revised form as "A Cyborg Manifesto: Science, Technology and Socialist-Feminism in the Late Twentieth-Century," in Simians, Cyborgs, and Women: The Reinvention of Nature (London and New York: Routledge, 1991), 149-81, 181.

2 Donna Haraway, "Reading Buchi Emecheta: Contests for 'Women's Experience' in Women's Studies," in in Simians, Cyborgs, and Women: The Reinvention of Nature (London and New York: Routledge, 1991), 109-24, 109. 3 Haraway, "Manifesto for Cyborgs," 149.

${ }_{4}$ For my fuller discussion of the literary and cultural explorations of technological bodies and subjects in the twentieth century and their relationship to the late-Victorian era see Alex Goody, "Robots, Cyborgs and the Technological Body," in Technology, Literature and Culture (Cambridge: Polity Press, 2011), 136-67.

5 Haraway, "Manifesto for Cyborgs," 169.

6 In the androcentric model of sex as I cite it here, "real" sex consists of "foreplay", followed by penetrative sex, culminating in male orgasm. It is the model that Rachel P. Maines confronts in her study of the use of vibrators in the treatment of hysteria, The Technology of Orgasm: "Hysteria", the Vibrator, and Women's Sexual Satisfaction (Baltimore: John Hopkins
} 
University Press, 1999). For further debate see for example Catherine A. Mackinnon "Sexuality" in Towards a Feminist Theory of the State (Cambridge MA: Harvard University Press, 1991), 126-54; Janice Moulton, "The Myth of the Neutral 'Man"” in Sexist Language: A Modern Philosophical Analysis ed. Mary Vetterling-Braggin (Totowa NJ: Littlefield Adams, 1981), 110-115; Marilyn Frye, "Lesbian 'Sex"' in Wilful Virgin: Essays in Feminism 1976-1992 (Freedom CA: Crossing Press, 1992), 109-19.

7 This is the case in France as well as Britain, see for example the stereotypical Nouvelle Femme with her cigarette and bicycle in the cartoon on the cover of Le Grelot (19 April 1896); reproduced in Mary Louise Roberts, Disruptive Acts: The New Woman in Fin-de-Siècle France (Chicago and London: University of Chicago Press, 2002), 24.

8 The term "close technocultural readings" is employed by Tamara Ketagbian to describe her methodology in The Lives of Machines: The Industrial Imaginary in Victorian Literature and Culture (Ann Arbor: University of Michigan Press, 2011), 5. Ketagbian's willingness to see affinities between contemporary work on technoculture and the human, and to use this to inform her examination of the literature and culture of the Victorian era, is in sympathy with my method in this article.

9 Oscar Wilde, The Picture of Dorian Gray (1891) (Oxford: Oxford University Press, 1981), 51. 10 Ibid., 85-86.

11 Ibid., 87.

12 Ibid., 103.

${ }_{13}$ Thomas Lovell Beddoes wrote "Pygmalion. The Cyprian Statuary" in the early 1820s while Arthur Hallam's "Lines Spoken in the Character of Pygmalion" was composed a decade later. Later in the century come pieces such as W. C. Bennett's "Pygmalion" (1857) and what Gail Marshall rightly terms the "necrophilic fantasy" of Robert Buchanan's juvenile poem "Pygmalion. An Allegory of Art"; Gail Marshall, Actresses on the Victorian Stage: Feminine Performance and the Galatea Myth (Cambridge: Cambridge University Press, 1998), 19.

14 Marie Lathers, The Aesthetics of Artifice: Villiers's L'Eve future (Chapel Hill: University of North Carolina Press, 1996), 36. See also Jane Davidson Reid, ed., The Oxford Guide to Classical Mythology in the Arts, 1300-1990s, 2 vols. (Oxford: Oxford University Press, 1993). As J. Hillis Miller notes, there are clear links between the myth of Pygmalion in which he creates his own ideal object of desire and the myth of Narcissus in love with his own reflection: "For Galatea, to see at all is to see Pygmalion and to be subject to him. It is as if Narcissus' reflection in the pool had come alive and could return his love", Versions of Pygmalion (Cambridge MA: Harvard University Press, 1990), 5.

15 The popularity of staged tableau in Victorian culture, the new access to and use of classical statuary and the popularity of waxwork exhibitions can all be placed in proximity to the cultural circulation of the Pygmalion myth. For the role of theatre and performance in the French negotiation of the New Woman and feminism see Roberts, Disruptive Acts: The New Woman in Fin-de-Siècle France.

16 Havelock Ellis, Studies in the Psychology of Sex, I, part 3 "Sexual Selection in Man"(New York: Random House, 1936), 188.

17 Ibid.

18 Thomas Carlyle, Sartor Resartus (1896), The Complete Works of Thomas Carlyle, volume 1, ed. Henry Duff Traill (Cambridge: Cambridge University Press, 2010), 32. 
19 Herman Melville, "The Paradise of Bachelors and the Tartarus of Maids" in The Heath Anthology of American Literature, ed. Paul Lauter, et al. 3rd ed. Vol. 1 (Boston: Houghton Mifflin, 1998). 2437-2454, 2448.

${ }_{20}$ Ketabgian, The Lives of Machines, 36, 37.

${ }_{21}$ In France La Fronde, founded by Marguerite Durand in December 1887, was closely identified in the public mind with the New Woman phenomenon but she was also a presence in other periodicals: as Mary Louise Roberts writes "In the 1890s and early 1900s, readers of such periodicals as the Journals de débats, the Revue des deux mondes, La Nouvelle Revue and La Revue encylopédique were exposed almost daily to articles, surveys, and editorials concerning the unruly "femme nouvelle", Roberts, Disruptive Acts, 6.

22 [Eliza Lynn Linton], "The Girl of the Period," The Saturday Review 25 (14 March, 1868), 339-40, 340.

${ }_{23}$ Max Beerbohm, "A Defence of Cosmetics" ("The Pervasion of Rogue") in The Works of Max Beerbohm (Dodd, Mead: New York, 1992), 107-135, 112.

${ }_{24}$ Beerbohm, "A Defence of Cosmetics," 133

25 Ibid., 112.

26 Ibid., 114.

${ }_{27}$ Sarah Wintle, "Horses, Bikes and Automobiles: New Woman on the Move," in The New Woman in Fiction and in Fact. Fin-de-Siècle Feminisms ed. Angelique Richardson \& Chris Willis (Basingstoke: Palgrave Macmillan, 2001), 66-78, 68.

28 Ibid., 72; woman cyclists appear in a range of New Woman fictions including George Egerton's "Her Share” (1894), Alice Meynell's “A Woman in Grey” (1896), and Kate Chopin's “The Unexpected” (1895).

${ }_{29}$ The masturbatory possibilities arising from the use of treadle sewing machines was also a nineteenth century concern.

30 Mary E. Kennard, The Golf Lunatic and His Cycling Wife (London: Hutchinson \& Co., 1902), 63.

31 Morag Shiach, "Modernity, labour and the typewriter," in Modernist Sexualities, ed. Hugh Stevens \& Caroline Howlett (Manchester: Manchester University Press, 2000), 114-129, 115. For an historical and sociological account of the typist in France see Delphine Gardey La Dactylographe et l'expéditionnaire: histoire des employés de bureau, 1890-1930 (Paris: Éditions Belin, 2001).

${ }_{32}$ Christopher Keep, "Blinded by the Type: Gender and Information Technology at the Turn of the Century," Nineteenth-Century Contexts, 23, no. 1 (2001), 149-73, 154.

${ }_{33}$ Shiach, "Modernity, labour and the typewriter", 116.

34 Ibid., 122.

35 Ibid., 121

${ }_{36}$ Kathryn Hughes, The Victorian Governess (London \& New York: Hambledon and London, 2001), 121.

37 On type-writer girl pornography see Christopher Keep, “The Cultural Work of the TypeWriter Girl," Victorian Studies 40, no.3 (1997), 401-27; for my further discussion of the "uncanny" type-writer see Goody, Technology, Literature and Culture, 110-14. 38 Jennifer Wicke, "Vampiric Typewriting: Dracula and its Media," English Literary History (ELH), 59 (1992), 467-493, 467.

${ }_{39}$ Bram Stoker, Dracula (London: Penguin, 2003), 230.

40 Ibid., 351. 
${ }_{41}$ For New Women writers on vivisection see Mona Caird's “Beyond the Pale: An Appeal on Behalf of the Victims of Vivisection" (1897)

<http://www.indiana.edu/ letrs/vwwp/caird/beyond.html> (accessed 28/06/10) and Frances Cobbe's "Vivisection in America" (1890)

<http://www.indiana.edu/ letrs/vwwp/cobbe/viviamer.html> (accessed 28/06/10).

${ }_{42}$ See Michael R. Finn, "Dogs and females: Vivisection, feminists and the novelist Rachilde," French Cultural Studies 23, no.3 (2012), 190-201.

43 For further discussion see Ornella Moscucci, The Science of Woman: Gynaecology and gender in England, 1800-1929 (Cambridge and New York: Cambridge University Press, 1990), especially "Woman and her diseases," 102-134.

${ }_{44}$ Elizabeth Blackwell, Pioneer Work in Opening the Medical Profession to Women (London:

Longmans, Green and Co, 1895), 72.

${ }_{45}$ Sarah Stage, Female Complaints (New York: Norton, 1979), 81-82.

${ }_{46}$ Quoted in Coral Lansbury, The Old Brown Dog: Women, Workers, and Vivisection in Edwardian England (Madison: University of Wisconsin Press, 1985), 89. For further details see the whole of Lansbury's chapter 5 "Horrible and Indecent Exposure", 83-104; see also Ann Dally Woman Under the Knife: A History of Surgery (London: Castle Books, 1991), 146-47.

${ }_{77}$ Lansbury, Old Brown Dog, x.

${ }_{48}$ Frances Power Cobbe, The Modern Rack: Papers on Vivisection (London: Swan Sonnenschein \& Co, 1889), 8 .

${ }_{49}$ Blanche is depicted in André Brouillet's 1887 painting “A Lesson at the Salpêtrière;" the life of Augustine has been fictionalised in the recent film by Alice Winocour (dir.), Augustine (Color, 2012, 102 min., France, Dharamsala, France 3 Cinéma, ARP Sélection). Asti Hustvedt's Medical Muses: Hysteria in Nineteenth-Century Paris (New York \& London: W.W. Norton and Company, 2011) explores Blanche, Augustine and Genevieve.

${ }_{50}$ Felicia McCarren, “The 'Symptomatic Act' Circa 1900: Hysteria, Hypnosis, Electricity, Dance," Critical Inquiry, 21 (Summer 1995), 748-74, 764.

51 Désiré Magloire Bourneville and Paul Regnard, Iconographique photographique de la Salpêtrière (Paris, 1878).

52 See Georges Didi-Huberman's discussion of the technical requirements and effects arising from the nature of late-nineteenth century photography such as needing to pose patients for minutes at a time, the darkening of images on wet collodion plates and the production of artificial paraluminous halos around the subject (Georges Didi-Huberman, Invention of Hysteria: Charcot and the Photographic Iconography of the Salpêtrière, trans. Alisa Hartz, Cambridge, MA: MIT Press, 2003).

53 Jean-Martin Charcot "Hysteroepilepsy: A Young Woman with a Convulsive Attack in the Auditorium" in Charcot the Clinician: The Tuesday Lessons, trans. and ed. Christopher G. Goetz (New York: Raven Press, 1987), 107.

${ }_{54}$ See Sander L. Gilman, "The Image of the Hysteric" in Gilman et al., Hysteria Beyond Freud (Berkeley: University of California Press, 1993), 345-452; and Georges Didi-Huberman, Invention of Hysteria.

55 J. M. Charcot, Lecture XI "Ovarian Hyperaesthesia" in Lectures on The Diseases of The

Nervous System. Delivered at La Salpêtrière, trans. George Sigerson (London: The New Sydenhan Society, 1879), 216-233, 223. 
56 J. M. Charcot and P. Richer, "Note on Certain Facts of Cerebral Automatism Observed in Hysteria during the Cataleptic Period of Hypnotism", Journal of Nervous and Mental Disease 10 (Jan, 1883), 1-13, 9.

57 Ibid.: 4 plates accompany the article on p.10.

58 J. M . Charcot, Oeuvres completes (Paris, 1886-1893) vol. 3, 337; quoted in translation in Asti Hustvedt, "Science Fictions: The Future Eves of Villiers de l'Isle Adam and Jean-Martin Charcot" in The Decadent Reader: Fiction, Fantasy and perversion from fin-de-siècle France, ed. Asti Husvedt (New York: Zone Books, 1998), 504.

59 See Maines, The Technology of Orgasm. Recent reflections on the use of vibrator technology to treat hysteria in the late nineteenth century include Sarah Ruhl's play In The Next Room, or The Vibrator Play which premiered at the Berkeley Repertory Theatre in February 2009 and on Broadway in November 2009

60 Alphonso David Rockwell makes this claim in The Medical and Surgical Uses of Electricity (New York: E. B. Treat, 1903), 635, 641. See also Maines, The Technology of Orgasm, 93-95. ${ }_{61}$ Maines, The Technology of Orgasm, 3.

${ }_{62}$ Daniel Gerould, "Villiers de l'Isle-Adam and Science Fiction," Science-Fiction Studies 11 (1984), 318-323, 318.

63 Villiers points to the marvellous nature of Edison's inventions in his preliminary "Advice to the Reader", while also taking care to point out that his Edison is a "symbolic legend," Villiers de L'Isle Adam, The Future Eve (L'Eve future) in The Decadent Reader: Fiction, Fantasy and perversion from fin-de-siècle France, 524.

${ }_{64}$ The neologism that Villiers creates is "l'Andréide," which literally translates as Andreid: I use this term rather than the anachronistic "android" that appears in English-language translations of The Future Eve.

${ }_{65}$ Villiers, The Future Eve, 632.

66 Ibid., 640.

${ }_{67}$ Villiers The Future Eve, 645.

68 Ibid., 642.

${ }_{69}$ Ibid., 641.

70 Villiers, The Future Eve, 550.

71 Ibid., 552.

72 Ibid., 563.

73 Ibid., 569.

74 Bloom, "Pygmalionesque Delusions," 301.

75 Ibid., 649.

76 Ibid., 667.

77 Ibid., 647.

${ }_{78}$ Carol de Dobay Rifelj argues that the scene between Hadaly and Ewald here anticipates the Turing Test in "Minds, Computers and Hadaly" in Jeering Dreamers: Essays on L'Eve future, ed. John Anzalone (Amsterdam: Rodopi, 1996), 127-39.

79 "The Doll” was published in Lee's For Maurice: Five Unlikely Stories (London: J. Lane, 1927), 207-23; it initially appeared as "The Image" in the Cornhill Magazine, May 1896; see Patricia Pulham, Art and the Transitional Object in Vernon Lee's Supernatural Tales (Aldershot: Ashgate, 2008), 105, 110 n.10, 113, n.44.

80 See for example "Introduction" in Christa Zorn, Vernon Lee: Aesthetics, History, and the Victorian Female Intellectual (Athens: Ohio University Press, 2003), and Laurel Brake "Vernon 
Lee and the Pater Circle"' in Vernon Lee: Decadence, Ethics, Aesthetics ed. Catherine Maxwell and Patricia Pulham (Houndmills: Palgrave Macmillan, 2006), 40-57.

${ }_{81}$ Dennis Denisoff, "Vernon Lee, Decadent Contamination and the Productivist Ethos" in Vernon Lee: Decadence, Ethics, Aesthetics ed. Catherine Maxwell and Patricia Pulham

(Houndmills: Palgrave Macmillan, 2006), 75-90, 77.

82 Lee, "The Doll”, in For Maurice: Five Unlikely Stories (London: J. Lane, 1927), 213-14.

83 Ibid., 209.

84 Ibid., 216.

85 Ibid., 217.

86 Mary Patricia Kane, Spurious Ghosts: The Fantastic Tales of Vernon Lee (Rome: Carocci, 2004), 99. Kane also draws connections between "The Doll" and Lee's essay The Economic Parasitism of Women (1898), a "text which is also concerned with representations of the feminine that diminish women in order to aggrandize men" (115).

${ }_{87}$ Lee, "The Doll", 222.

88 Ibid, 223.

89 Kane, Spurious Ghosts, 100.

90 Hoffman's influence on Lee's fantastic tales has been noted by critics: see Kane, Spurious Ghosts, 46, Patricia Pulham Art and the Transitional Object, xix and 98ff.

91 Lee's For Maurice: Five Unlikely Stories is dedicated to Maurice Baring and the "Introduction" is addressed specifically to him.

92 Lee, "Introduction" in For Maurice, xlv.

93 Kane, Spurious Ghosts, 117.

${ }_{94}$ Susan J. Navarette sees in “The Doll” Lee's denunciation of Mariolatry and its influence on the construction of the Victorian domestic angel: see Chapter 4 of Navarette's The Shape of Fear: Horror and the Fin de Siècle Culture of Decadence, (Louisville: University of Kentucky Press, 1998). Similar to my reading here, Patricia Pulham suggests there is more at stake in "The Doll" than a critique of the position of women in patriarchal society, and that attention should be paid to sexuality and the affinity between the narrator and the doll. However, what Pulham sees is an expression of "a veiled homoerotic desire", arguing that the "figure of the doll ... symbolizes the body of the mother" (Pulham, Art and the Transitional Object, 107). ${ }_{95}$ Rachilde was not a feminist, as her 1928 pamphlet Pourquoi je ne suis pas féministe details, but she was close friends with the anti-vivisectionist French feminist Marie Huot, see Finn "Dogs and females."

${ }_{96}$ Hannah Thompson, "Rewriting the Perverse: Rachilde and the Erotic Body." Nottingham French Studies, 24, no. 2 (Autumn, 2003), 26-34, 27.

${ }_{97}$ Ibid.

98 Rita Felski, The Gender of Modernity (Cambridge MA: Harvard University Press, 1995), 197. 99 Thompson, "Rewriting the Perverse", 31.

100 Rachilde, Monsieur Venus (1884), trans. Madeleine Boyd in The Decadent Reader: Fiction, Fantasy and Perversion from fin-de-siècle France, ed. Asti Husvedt (New York: Zone Books, 1998), 312.

101 Ibid., 314.

102 Ibid., 342, 327, 351.

103 Felski, Gender of Modernity, 198.

104 Rachilde, Monsieur Venus, 366.

105 Felski, Gender of Modernity, 198. 
106 Thompson, "Rewriting the Perverse," 33.

107 Rachilde, The Juggler [La jongleuse], trans. Melanie C. Hawthorne (1900; New Brunswick: Rutgers University Press, 1990), 23.

108 See Rae Beth Gordon, Ornament, Fantasy and Desire in Nineteenth-Century Literature (Princeton: Princeton University Press, 1992).

109 The term "machinic" here is a deliberate echo of Deleuze and Guattari's use of the term in their writing and their understanding of desire as always machined and never "natural," part of their description of the world as a "mechanosphere" of assembled and fabricated proximities, meanings and affects (Gilles Deleuze and Felix Guattari, A Thousand Plateaus: Capitalism and Schirophrenia, trans. Brian Massumi, London: Athlone Press, 1988, 514; see also Deleuze and Guattari, Anti-Oedipus: Capitalism and Schizophrenia, trans. Robert Hurley, Mark Seem and Helen R. Lane, London: Athlone Press, 1984, especially part 1, "Desiring Machines").

110 For further details and illustrations see Maines, Technology of Orgasm, 100-108.

111 For a discussion of how vibrators and other sex toys "subvert the meaning of the phallus and undermine men's ultimate power to 'please' women via penetration" which considers the sexual practices of lesbian, bi-sexual and heterosexual women see Breanne Fahs and Eric Swank, "Adventures with the 'Plastic Man': Sex Toys, Compulsory Heterosexuality, and the Politics of Women's Sexual Pleasure,” Sexuality and Culture 17 (2013), 666-685, 670. 